\title{
KEGIATAN REPORTASE BERITA KOTA OLEH WARTAWAN SURAT KABAR HARIAN RAKYAT BENGKULU
}

\author{
Oleh: \\ INDRIA \\ Dosen Tetap Prodi Ilmu Komunikasi Fakultas Ilmu Sosial UNIVED Bengkulu
}

\begin{abstract}
The reporters of Rakyat Bengkulu daily newspaper should have the ability and skill to find and collect the facts in accordance with the planned news in reporting activities. In this research, researcher came directly and conducted direct observation into the reporting activities, projection meeting and writing news. Interviews were also conducted with the editors and reporters of Rakyat Bengkulu daily newspapers about the editorial policy. Reporting activities by Rakyat Bengkulu daily newspaper reporters was activities which was started from the meeting projections, seek for information about an issue, mews typing and news editing, followed by the editor decisions whether the news was proper published or not.
\end{abstract}

Keywords: news, reporting activities, reporters

\section{PENDAHULUAN}

Kualitas yang disajikan pada sebuah media tidak terlepas dari hasil reportase yang dilakukan oleh wartawan karena wartawan adalah seorang yang bertugas mencari, mengumpulkan, dan menulis berita untuk diterbitkan di surat kabar, majalah dan sebagainya. (Soewardi Indris 2004:2 dalam Zalmi Herawati).

Wartawan surat kabar harian Rakyat Bengkulu dalam melakukan kegiatan reportase atau liputan (mencari dan memburu berita) harus memiliki kemampuan dan keterampilan melakukan, menemukan dan mengumpulkan fakta sesuai dengan berita yang telah direncanakan sebelumnya, dengan menggunakan seluruh inderanya: mata, telinga, hidung, kulit dan lidah serta indera keenam yaitu intuisinya untuk mengumpulkan data dan fakta dilapangan.

\begin{abstract}
Wartawan surat kabar harian Rakyat Bengkulu melakukan reportase diawali dari rapat proyeksi yang dipimpin oleh Redaktur dan Pimpinan Redaksi untuk menentukan berita yang akan diliput, serta membahas nilai berita yang terkandung dari berita tersebut, kemudian dilanjutkan dengan reportase di lapangan, selain reportase berita yang telah diproyeksi, wartawan juga meliput atau mereportase berita yang dihunting di lapangan kemudian wartawan menyelesaikan kegiatan reportase dengan mampu menyajikan berita tersebut ke dalam tulisan yang akan masuk ke meja redaksi untuk diedit.

Wartawan sebagai ujung tombak pemberitaan, dituntut mencari berita yang memenuhi 3 syarat penting dari sebuah berita, yakni : (1) Apakah berita itu cukup penting (important)? (2) Apakah berita itu cukup baru (actual)? dan (3) Apakah berita itu cukup menarik (interest).
\end{abstract}


Selain mencari berita, wartawan juga harus mampu menulis berita dari data yang telah didapat di lapangan. Wartawan harus mampu menentukan sudut pandang berita yang tepat, judul, lead, tubuh (body berita yang memuat detil atau uraian) dan penutup berita. Maka dalam penulisan harus memasukkan unsur 5W+1 yakni What (Apa), Who (Siapa), When (Kapan), Where (Dimana), Why (Mengapa) dan How (Bagaimana).

Banyak sekali tugas yang harus dipikul oleh seorang wartawan dari mencari dan mengumpulkan berita, melakukan wawancara dan menuliskan berita, yang kesemuanya itu harus dibarengi dengan kemampuan dan keterampilan agar tugasnya dapat terlaksana dengan baik, terutama untuk media yang terbit harian seperti halnya surat kabar harian Rakyat Bengkulu. Adapun tujuan dari penelitian adalah untuk mengetahui kegiatan reportase berita yang dilakukan oleh wartawan di surat kabar harian Rakyat Bengkulu.

\section{METODE PENELITIAN}

Dalam penelitian ini penulis melakukan pengamatan secara langsung pada objek yang diamati. Untuk memperoleh penjelasan data, penulis melakukan penelitian selama satu bulan pada surat kabar harian Rakyat Bengkulu. Dalam proses penelitian tersebut penulis langsung terjun ke lapangan melakukan kegiatan reportase, mengikuti proyeksi dan menulis berita. Wawancara dilakukan kepada redaktur dan wartawan surat kabar harian Rakyat Bengkulu mengenai kebijakan redaksional terhadap format isi, gaya bahasa yang digunakan, tantangan dan hambatan yang dihadapi saat kegiatan reportase dan sebagainya. Pada dasarnya pengumpulan data dalam kegiatan penelitian ini berpedoman pada kerangka obyek pengamatan. Untuk memberikan acuan atau pedoman bagi peneliti, maka dibuat semacam pedoman dasar tentang yang akan diungkapkan sesuai dengan kebutuhan dan tujuan pencarian data, maka disusun pedoman dasar wawancara. Studi pustaka dilakukan melalui pengumpulan data dengan mempelajari masalah yang berhubungan dengan objek yang diteliti serta sumbersumber dari buku-buku pedoman literatur yang disusun para ahli. Teknik Analisa data dalam penelitian ini mengunakan analisis deskriptif yakni pemecahan masalah yang diselidiki dengan menggambarkan atau melukiskan keadaan subjek penelitian (seseorang, lembaga, perusahaan, masyarakat, dan sebagainya) pada saat sekarang dan berdasarkan fakta yang tampak.

\section{HASIL PENELITIAN DAN PEMBAHASAN}

Berdasarkan hasil penelitian dan temuan di lapangan maka dapat ditemukan beberapa kegiatan reportase pada surat kabar harian Rakyat Bengkulu, yaitu:

\section{Rapat Proyeksi}

Rapat proyeksi di surat kabar Harian Rakyat Bengkulu dilakukan pada pukul 08.00 setiap hari minggu dan hari libur. Rapat proyeksi dipimpin oleh redaktur, dihadiri oleh wartawan yang bertugas mencari berita di kota Bengkulu berjumlah 7 orang, rapat juga dikontrol oleh pimpinan redaksi, terkadang rapat juga dihadiri oleh general manager dan redaktur pelaksana.

Rapat proyeksi membicarakan mengenai berita yang akan diliput oleh wartawan serta nilai yang terkandung dalam berita yang akan diliput, mengajukan tempat liputan yang akan dituju dan nara sumber yang akan diwawancarai, kemudian didiskusikan dengan semua orang yang mengikuti rapat, dalam rapat juga membahas 
berita yang akan diliput tersebut disesuaikan dengan kriteria yang dinginkan oleh pemberitaan Rakyat Bengkulu dan menyesuaikan nara sumber yang tepat untuk diwawancarai.

Dalam rapat proyeksi, untuk bahan liputan surat kabar harian Rakyat Bengkulu menggunakan acuan dari Koran Rakyat Bengkulu yang terbit pada hari itu, koran lokal lain yang terbit di Bengkulu, koran bersekala nasional (Kompas) dan koran dari provinsi lain (Radar Lampung, Palembang Pos).

Lamanya rapat proyeksi biasanya tidak pernah ditentukan, bila permasalahan yang dibahas cepat selesai maka semakin cepat pula wartawan melakukan kegiatan reportase. Biasanya rapat selesai antara pukul 09.00-10.00 WIB setiap harinya. Bila hari minggu dan tanggal merah wartawan masih mencari berita tapi tidak rapat proyeksi. Namun pada tanggal merah surat kabar harian Rakyat Bengkulu tidak terbit, jadi berita yang diliput oleh wartawan diterbitkan setelah tanggal merah tersebut (lusa).

Pada saat proyeksi berlangsung
redaktur juga menyarankan kepada
wartawan membawa kamera untuk mengambil foto kejadian yang diliput, baik foto untuk berita yang telah diproyeksikan maupun yang dihunting di lapangan Karena foto dianggap dapat menarik perhatian pembaca.

Wartawan dituntut agar bisa menghasilkan berita atau informasi yang sesuai dengan kenyataan yang ada dilapangan. Wartawan tidak boleh menyampaikan berita bohong dan tidak sesuai dengan kenyataan yang ada di lapangan. Untuk menghindari ketidak seimbangan berita atau informasi, wartawan terlebih dahulu harus mengadakan konfirmasi kepada sumber-sumber yang akan diberitakan (chek and richek) agar tidak terjadi tumpang tindih dalam penyampaian berita terutama pada berita terutama pada berita konflik antara kelompok dengan kelompok atau seseorang dengan seseorang.

\section{Wartawan/Reportase Saat Melakukan Reportase}

Setelah rapat proyeksi selesai, wartawan langsung hunting berita dilapangan, mencari berita yang telah ditugaskan oleh redaktur maupun yang didapat dari ide sendiri. Sebelum menemui narasumber yang akan diwawancara, sebaiknya wartawan mempersiapkan diri untuk menguasai permasalahan, baik itu dengan membaca buku maupun bertanya kepada redaktur wartawan lainnya.

Ketika wartawan turun ke lapangan, wartawan RB mendahulukan berita yang telah direncanakan dalam rapat proyeksi, namun apabila di lapangan wartawan menemukan hal-hal yang dianggap layak dijadikan berita maka wartawan juga meliputnya. Lama waktu yang dibutuhkan oleh seorang wartawan saat meliput sebuah berita tidak dapat ditentukan, tergantung dengan jumlah nara sumber yang akan diwawancarai dan jenis berita yang diliput, karena jika berita yang diliput merupakan berita konflik maka harus mewawancarai beberapa orang yang dapat dijadikan narasumber sehingga berita yang ditulis dapat berimbang dan adil.

\section{Penelitian Berita}

Redaktur memberikan waktu kepada wartawan kembali ke kantor untuk mengetik berita dimulai pada pukul 15.00 Wib, dan menyelesaikan ketikan pada pukul 17.30 WIB, meski demikian banyak wartawan yang kembali ke kantor lewat dari pukul 15.00 WIB begitu juga dalam pengetikan berita. Namun hal ini dapat dimaklumi oleh redaktur, karena redaktur tahu kendala yang dihadapi oleh wartawan di lapangan, dengan konsekuensi wartawan 
yang lama menyelesaikan hasil ketikannya harus pulang larut malam sehingga beritanya selesai diedit. Kalimat utama atau lead adalah bagian yang paling sulit untuk ditulis, wartawan harus berfikir keras menulis bagian ini, namun ini tidak sulit jika saat akan melakukan peliputan, wartawan telah tahu sudut pandang dan tujuan Penelitian berita yang diliput. Saat lead telah ditulis, kalimat pada paragraf berikutnya akan terasa lebih mudah dan mengalir sendiri sehingga pada kalimat penutup.

Hal yang harus dingat seorang wartawan yakni $5 \mathrm{~W}+1 \mathrm{H}$ yang sebaiknya terdapat dalam berita, sehingga pembaca merasa jelas dan mengerti isi berita. Berita menggunakan piramida terbalik, dengan mendahulukan menulis hal penting yang ingin diketahui oleh bagian yang kurang penting.

\section{Pengeditan Berita}

Pengetikan berita yang dilakukan oleh redaktur merupakan bentuk kerjasama antara redaktur dan wartawan yang harus dilakukan. Dalam proses pengeditan, redaktur memeriksa dan memperbaiki kalimat yang dibuat wartawannya agar sesuai dengan kriteria pemberitaan atau standar yang ditetapkan pada Rakyat Bengkulu, redaktur juga memeriksa tata bahasa, judul, lead, body dan penutup berita serta kelengkapan data, fakta dan keakuratan berita tersebut.

Sebelum berita selesai diedit maka wartawan tidak diperbolehkan pulang, ini bertujuan apabila berita yang ditulis terdapat kekurangan dan kesalahan atau tidak jelas, maka redaktur dapat menanyakan langsung pada wartawan yang bersangkutan, sehingga wartawan tahu bagian yang salah dan bagian yang harus diperhatikan saat peliputan berita, sehingga tidak terjadi kesalahan yang sama saat menulis berita.

Berita yang diliput oleh wartawan daerah masuk ke redaktur melalui internet, sehingga wartawan daerah tidak perlu menulis berita dikantor. Namun jika berita yang dikirimkan oleh wartawan tersebut terdapat menghubungi wartawan yang bersangkutan melalui telefon. Berita yang akan naik cetak merupakan berita yang benar-benar lengkap, akurat, berimbang, hangat, penting bagi sebagian besar orang, dan sesuai dengan criteria berita Rakyat Bengkulu, sehingga berita yang tidak memenuhi hal tersebut kemungkinan besar tidak akan diedit dan tidak akan dicetak.

\section{Kinerja Wartawan}

Latar belakang pendidikan wartawan surat kabar harian Rakyat Bengkulu tidaklah harus jurnalistik, kebanyakan yang memilki latar belakang pendidikan dari Ekonomi, Politik, Pertanian, Sosiologi dan hanya satu orang dengan latar belakang pendidikan Jurnalistik. Namun hal ini tidak membatasi mereka dalam melakukan kegiatan reportase, seperti wartawan perempuan satu-satunya di Rakyat Bengkulu yang telah bekerja selama 6 tahun mejadi seorang wartawan, dengan latar belakang pendidikan sosiologi, ia mampu menyelesaikan tugas yang diberikan dengan baik.

Mempraktekkan teori jurnalistik yang didapat di bangku kuliah tidak semudah yang dibayangkan, perlunya ilmu tambahan yakni mental atau keberanian saat menemui narasumber, apalagi narasumber adalah orang yang anti dengan surat kabar, karena dalam sebuah pemberitaan pastilah ada yang suka dan ada yang tidak. Menjadi seorang wartawan bukan hanya karena kecantikan dak kegagahan, bukan karena keluesan bergaul, bukan hanya karena rasa ingin tahu, bukan juga hanya pengetahuan luas dan dalam, melainkan ketekunan, kegigihan dan vitalitas. 


\section{KEGIATAN REPORTASE}

Dalam melakukan kegiatan reportase banyak hal yang harus diperhatikan seorang wartawan sehingga berita yang dihasilkan maksimal wawancara adalah teknik yang paling sering digunakan dalam menggali berita di lapangan, namun terdapat berita-berita tertentu yang didapat dengan melakukan observasi, biasanya digunakan dalam meliput berita kriminal seperti kecelakaan, pembunuhan, namun tetap diiringi dengan wawancara kepada narasumber, sehingga memperkuat kebenaran berita yang ditulis.

Selain menggunakan teknik yang baik dalam kegiatan reportase untuk mendapatkan hasil yang baik, seorang wartawan juga harus menjaga nama baik surat kabar harian Rakyat Bengkulu, karena Rakyat Bengkulu yang merupakan media pertama dan terbesar di Bengkulu, kesalahan yang dilakukan oleh wartawan di lapangan akan fatal akibatnya kepada RB, dari segi kepercayaan masyarakat terhadap berita yang dimuat yang mengakibatkan minat pembaca menurun, selain juga berdampak pada narasumber yang akan diwawancarai, narasumber akan malas diwawancarai karena nama baik RB yang buruk akibat melakukan wartawannya, dan dampak lainnya.

\section{Hunting Berita Ke Lapangan}

Biasanya saat berada di lapangn mencari berita, wartawan berita kota tidak pernah pulang kekantor dengan tangan kosong. Selalu mendapatkan informasi, data dan fakta yang membutuhkan untuk membuat berita, hal ini dikarenakan dalam setiap diri wartawan sudah tertanam rasa tanggung jawab, bahkan penerbitan surat kabar harian Rakyat Bengkulu adalah dari hasil kerja mereka. Jika mereka tidak memperoleh berita maka tidak dapat terbit.

Masing-masing wartawan berita kota/metropolitan memiliki wilayah liputan tersendiri dan biasanya ditempatkan di pospos yang berbeda, tetapi tidak menutup kemungkinan mereka untuk saling membantu dalam mencari berita.

\section{Pengetikan dan Pengeditan Berita}

Pengetikan berita yang dilakukan oleh wartawan berita kota terkadang-kadang lama, ini dikarenakan data dan fakta yang ditulis harus seakurat mungkin dan tata bahasanya juga harus jelas dengan menggunakan bahasa Jurnalistik. Sehingga lama pula berita tersebut diedit oleh redaktur berita kota, selain itu juga berita yang diketik oleh wartawan kadang kala ada tata bahasa kalimat dan kata-kata kurang tepat untuk ukuran pemberitaan Rakyat Bengkulu. Informasi yang diperoleh wartawan yang diperoleh di lapangan ada juga yang kurang lengkap hingga sering terlihat wartawan menghentikan pengetikan berita untuk menghubungi narasumber untuk meminta keterangan melalui telpon.

Judul, lead, bodi serta penutup berita yang dilakukan oleh wartawan masih ada yang dinilai oleh redaktur kurang tepat peletakkannya mana yang dianggap lebih penting untuk dijadikan judul dan teras berita maupun lead serta penutup berita, demikian juga dengan sudut pandang dengan anglenya. Kelengkapan dan fasilitas yang dimiliki wartawan SKH Rakyat Bengkulu, yakni tersedianya ruang redaksi yang dilengkapi dengan computer dan internet, tersedianya telpon, faximile, internet serta kamera foto, juga alat cetak yang canggih milik Rakyat Bengkulu, dan alat-alat yang menggunakan teknologi canggih lainnya.

\section{Kriteria Layak Berita}

Kriteria layak berita yang ditetapkkan oleh pimpinan redaksi SKH Rakyat Bengkulu merupakan standar yang memang harus dipenuhi dalam suatu pemberitaan, ini ditetapkan untuk wartawan 
dalam membuat berita agar berita yang disajikan kepada pembaca merupakan berita yang berkualitas sehingga surat kabar Rakyat Bengkulu tetap laku di pasaran walaupun banyak surat kabar lain yang bermunculan di Bengkulu yang menambah ketatnya persaingan untuk merebut pangsa pasar (konsumen).

\section{Teknik Peliputan Berita Kota}

Beberapa teknik liputan berita kota yang sering digunakan wartawan Rakyat Bengkulu :

a. Sistem ngepos yakni menempatkan wartawan berita kota pada posnya masing-masing seperti kontor Walikota, kontor DPR, Kantor Gubernur, instansiinstansi pemerintah lainnya, karena tempat-tempat seperti ini merupakan tempat yang tepat untuk peliputan berita kota. Namun wartawan mengingat berita kota sangat luas cakupannya bisa saja ada peristiwa yang terjadi di luar pos.

b. Kriteria layak berita yang ditetapkan oleh pimpinan redaksi SKH Rakyat Bengkulu merupakan standar yang memang harus dipenuhi dalam suatu pemberian, ini ditetapkan untuk wartawan dalam membuat berita agar berita yang disajikan kepada pembaca merupakan berita yang berkualitas sehigga Koran RB tetap laku dipasaran walaupun banyak Koran lain yang bermunculan di Bengkulu yang menambah ketatnya persaingan untuk merebut pangsa pasar (Konsumen).

\section{Bentuk Kerjasama Antara Redaktur Dan Wartawan}

Kerjasama antara redaktur dan wartawan SKH Rakyat Bengkulu terjalin dengan baik, semua wartawan menerima arahan dan petunjuk yang diberikan oleh redaktur. Berita yang dibuat oleh wartawan ada juga yang dibuat atas perintah redaktur.
Redaktur berita kota sering mengeluh lambatnya wartawan berita kota dalam mengetik berita, menyebabkan pengeditan dan percetakannyapun menjadi lama, sehingga redaktur harus pulang larut malam menunggu selesai dicetak. Selain itu kadangkala wartawan sering lupa menyampaikan berita yang ia temui di lapangan dan itu tidak ada dalam rencana berita, keesokan harinya baru diketahui dan redaktur langsung menanyakan karena berita itu diterbitkan oleh koran lain. Kerjasama antara redaktur dengan wartawan juga dapat dilihat dari ;

a. Rapat proyeksi, membahas masalah wilayah liputan, tema liputan dan narasumber yang akan diwawancarai serta kinerja wartawannya.

b. Mengedit berita, berita yang telah selesai diketik oleh wartawan kemudian diedit oleh redaktur, wartawan tidak bisa pulang sebelum redaktur selesai mengedit berita yang telah di tulis oleh wartawan.

Berdasarkan dari hasil temuan dilapangan mengenai kegiatan reportase, maka sebagai tolak ukur penulis dalam membahas kegiatan reportase, maka penulis memberikan beberapa sampel berita yangtelah diliput dengan mengunakan berbagai macam teknik reportase, diantaranya dapat dilihat sebagai berikut :

\section{Sampel 1}

Judul : Dituduhkan Serakah, Kyai Protes Depag

Edisi : Rabu, 20 Februari 2011

Teras berita : Kanwil Depag Provinsi Bengkulu diprotes, kali ini dating dari Pemimpin Ponpes Hidayatul Mubtadin (HM), KH Abdul Muntaqin Ahmad. Ponpes yang beralamat di jalan Rinjani ini menyesalkan sikap pihak Depag yang menuduh dirinya serakah, hanya karena mempertanyakan dana bantuan untuk Ponpes HM. 
Tubuh berita : Berisi ringkasan yang merupakan kelanjutan dari teas berita. data pokok yang telah ditulis pada teras berita diuraikan lagi secara rinci.

" Muntaqin mengaku kecewa, karena Ponpes yang baru berdiri dan belum ada santrinya justru mendapatkan bantuan dari Depag. Sementara Ponpes yang diasuhnya telah berdiri 8 tahun dengan ratusan santri, justru berkesan diabaikan................".

Akhir berita: merupakan kelanjutan dari tubuh berita dan merupakan pengembangan dari tubuh berita.

'Kyai NU ini menduga, peristiwa tersebut ada kaitan dengan permasalahan bantuan sebesar Rp. 2,5 juta yang dulu pernah diterimanya dari Kasi Ponren Kanwil Depag. Kala itu, bantuan tersebut dimintai untuk dikembalikan lagi tanpa sebab yang jelas, namun oleh Muntaqin, hal tersebut ditolak...........".

Apa tanggapan Kanwil Depag Propinsi Bengkulu, Drs. H. Mukhtahirin Baijuri, MM? Kepada Rb tadi malam, Mukhtahidi mengaku tidak tahu menahu soal bantuan ke Ponpes HM.............".

Teknik Reportase: Sampel diatas didapat dengan mengunakan teknik reportase yang disebut Teknik Tip, karena reportasenya yang disebut Teknik Tip, karena informasinya didengar dari seseorang kemudian dikonfirmasi dan dilengkapi lagi data yang diperlukan kepada yang bersangkutan, karena ini merupakan kejadian yang melibatkan beberapa orang. Maka perlu mewawancarai orang yang berhak untuk diwawancarai.

\section{Sampel 2}

Judul : KDRT di Kota Terus Meningkat Tiap Tahun

Edisi : Sabtu, 23 Februari 2011

Teras berita: Kekerasan Dalam Rumah Tangga (KDRT) masih menempati peringkat keatas dalam rengking jenis kekerasan yang menimpah perempuan di Kota Bengkulu tahun 2007 dan awal tahun 2008 dengan 81 kasus, disusul pelecehan seksual dengan 18 kasus dan perkosahan 17 kasus.

Tubuh berita: Berisiringkasan yang merupakan kelanjutan dari teras berita. Data pokok yang telah di tulis pada teas diuraikan lagi secara terinci.

"Menurut Program manager WCC Teti Sumeri, tingkat kekerasan yang paling banyak menimpa perempuan adalah KDRT. Dari sekian banyak kasus kekerasan terhadap perempuan, 60 hingga 65 persen merupakan kasus KDRT......."

Akhir berita: Merupakan kelanjutan dari tubuh berita serta pengembangan gagasan dari tubuh berita.

"Pihak WCC sangat menyayangkan masih banyaknya warga khususnya perempuan yang mengalami kekerasan namun tidak melapor kepada pihak berwajib atau kepada lembaga-lembaga perlindungan perempuan seperti WCC untuk mempermudah menyelesaikan kasus yang mereka alami”.

Teknik Reportase: Sampel ke dua ini, teknik reportase yang digunakan yakni sistem beat, dengan melakukan wawancara kepada pihak-pihak yang berhak untuk dimintai dana atau keterangan untuk memberikan fakta yang benar kepada pembaca.

\section{PENUTUP}

Kegiatan reprtase oleh wartawan surat Kabar Harian Rakyat Bengkulu, merupakan kegiatan yang dimulai dari rapat proyeksi, hunting berita di lapangan, pengetikan dan pengeditan berita serta keputusan redaktur mengenai banyak atau tidaknya berita itu diterbitkan. Setiap hari (kecuali hari libur dan minggu) pada pukul 08.00 WIb. Dilakukan rapat proyeksi untuk menentukan rencana berita yang akan diliput serta membahas kinerja wartawannya.

Wartawan Rakyat Bengkulu selain meliput berita juga mengambil foto berita 
yang diliput jika diperlukan, foto tersebut sebagai penguat kebenaran dari berita.

Melakukan kerjasama antara redaktur dengan wartawan dan antara wartwan dengan wartawan lainnya dalam hal menentukan liputan berita yang akan dicari dan diterbitkan.

Di dalam peliputan berita (reportase) pada surat kabar harian Rakyat Bengkulu, wartawan telah dibagi wilayah liputan (bite), namun untuk calon wartawan (CW) wilayah liputan masih bebas (hunting berita di lapangan). Surat Kabar Harian

\section{DAFTAR PUSTAKA}

Asegaf Dja'far. 1985. Jurnalistik Masa Kini. Ghalia Indonesia. Jakarta Timur.

Bambang dan dkk, 2006. Mahir Berjurnalistik. Amara Books. Yogyakarta

Djoroto Totok, 2002. Manajemen Penerbitan Pers. Remaja Rosda karya. Bandung.

Herawati Zalmi, 2004. Kegiatan Peliputan Berita Oleh Wartawan. Laporan Tugas Akhir.

Hikmat dkk, 2006. Jurnalistik Teori dan Praktek. Remaja Rosda Karya. Bandung.

Pernama dkk, 2006. Teori Jurnalistik. Remaja Rosda Karya. Bandung

Stein M.L, 1993. Bagaimana Menjadi Wartawan. Rineka Cipta. Jakarta.

Syamsul Asep, 2006. Jurnalistik Praktis. Remaja Rosda Karya. Bandung.

T. Simbolon Parakitri. 2006. Vademekum Wartawan. Kepustakaan popular Gramedia. Jakarta.
Rakyat Bengkulu wartawan dilatih untuk jeli dalam membaca situasi agar mendapatkan informasi dengan cara, setiap hari rapat proyeksi berlangsung redaktur dan redaktur pelaksana yang memimpin rapat, memberikan berbagai macam contoh peristiwa yang dapat dijadikan bahan berita meskipun kejadian itu belum diketahui oleh orang lain, selain itu juga redaktur juga memberikan berbagai saran dalam meliput berita, baik dari segi pertanyaan, mencari sudut permasalahan, dan sebagainya.

Widodo, 1997. Teknik Wartawan di Surat Kabar dan Majalah. Indah. Surabaya.

Yurnaldi, 1992. Kiat Praktis Jurnalistik. Angkasa Raya. Padang. 